\title{
MONEY SUPPLY MODEL IN MUSLIM COUNTRIES
}

\author{
Nanda Suhanda \\ Bandung City Education Office, Indonesia \\ Email: nandasuhanda98@gmail.com \\ Hamdan Firmansyah \\ IAIRM Wali Songo Islamic Boarding School, Ngabar Ponorogo Indonesia \\ Email: abihilqi@gmail.com
}

\begin{abstract}
Efforts to control economic conditions in a country are called monetary policy. The main thing is to regulate the stability of the value of money and the amount of money circulating in the homeland of each country. This macro policy is expected to be able to respond to micro economic growth so that real economic growth will be realized. The economic success of a country is largely determined by the precise determination of monetary policy. This policy was created in response to the microeconomics which was then managed in a macro manner by policy makers. This policy making step must be in accordance with the sharia scenario so that the economic growth is expected to get a blessing so that falah is the ultimate goal of the economy as well as being realized as the policy is taken. A literature review was finally taken in order to find answers to this essential monetary policy concept. The final goal of the discussion of sharia economic policy is to maintain and maintain the stability of the country's economy.
\end{abstract}

Keywords: Money, Stability, Economy

\section{A. INTRODUCTION}

Monetary policy is not something that stands alone, but there is interdependence on various variables in the economy. On the one hand, monetary policy is heavily influenced by various factors in the economy, on the other hand, monetary policy directly affects monetary and financial conditions, which in turn will have an impact on conditions in the real sector or real sector (Pohan, 2008).

Monetary policy is a central bank instrument that is deliberately designed in such a way as to influence financial variables such as interest rates and the level of money supply. The target to be achieved is to maintain the stability of the value for money, both internal and external factors. The stability of the value of money reflects price stability which in turn will affect the realization of the achievement of a country's development goals, such as the fulfillment of basic needs, equitable distribution, expansion of job opportunities, optimum real economic growth and economic stability (Rahardja \& Manurung, 2004)

This form of interest, along with its characteristics, promises a fixed and pre-determined return in the economy, creating a unique activity in the economy as a whole. The existence of this interest then also has consequences that are so fundamental in the economy (Sakti, 2007). In the conventional monetary system, an instrument used as a monetary monetary policy tool is basically shown to control the money supply in society, be it individuals, groups or business units.

In this way, monetary policy with its instrument (interest) will be able to control the preferences of the fund owner not to play in the financial market which will affect economic stability through both financial markets and consumptive behavior. While in Islam naturally the system will not have a tendency like conventional, the system does not allow speculative practices and encourages frugal consumption behavior. 
Islam does not allow interest to exist in the market, thus there is no tendency for money creation through the banking sector which then inflates the amount of money which further widens inequality in the monetary and real sectors. Besides, the absence of interest in the economy also means that there are no factors that tempt fund holders to hold their money in the financial market, where the more the financial market develops, the more money is held back and this also leads to a deeper gap between the monetary and real sectors. So, seeing the basis of this philosophy, the focus on money supply to set monetary policy and its instruments in the form of a certain interest rate becomes irrelevant.

The focus of Islamic monetary policy is more focused on maintaining the rotation of economic resources, which is the core of Islamic economics in all forms of policies and provisions permitted by sharia. Thus in Islam, regulators simply have to ensure the availability of sharia economic and financial products that are able to absorb the "investment potential" of the community, or provisions that encourage preference for the use of "investment potential" in productive businesses to occur.

That way, the time to hold money by each fund owner will be minimized as possible, which time actually hinders velocity. In other words, the provision of regulations in the form of business opportunities, Islamic financial products and other provisions relating to the flow of money in society. Will further increase the velocity in the economy. Thus the attention of monetary regulation is not focused on the concept of money supply as adopted by conventional means, but rather on economic velocity.

One of the most important Islamic teachings for upholding justice and eliminating exploitation in business transactions is to prohibit all forms of unfair increase in wealth. One of the important sources of unauthorized increase in wealth is receiving monetary gain in a business transaction without providing a real reward in kind. Riba represents in the Islamic value system a major source of unauthorized profit (Chapra, 2000).

The Islamic financial system is actually a complement and a complement to the Islamic economic system based on production and trade, or what is known as the real sector. High activities in the fields of production and trade will increase the money supply, while economic activities will result in lower circulation and the money supply (Huda, 2009).

In an Islamic economy money is not capital. Money is an item of the public at large. Money is not a person's monopoly good. So everyone has the right to have money in effect in a country. Meanwhile, capital is personal or individual goods. If money is a flow concept while capital is a stock concept (Suprayitno, 2005). In economic life, money has an important role, among others, money is the standard value for existing economic activities, whether consumption, production, or reflection on wealth and income. Money can make it easier for us to barter for goods and services among individual communities (Mujahidin, 2007).

In an Islamic economy, the demand for money will arise mainly from the motive of transactions and precautionary measures which are generally determined by the level of income of money and its distribution. The demand for money because of the speculative motive is basically driven by fluctuations in interest rates in the capitalist economy. A decrease in interest rates coupled with expectations about an increase will encourage individuals and companies to increase the amount of money held. Because interest rates fluctuate frequently in a capitalist economy, there is a continuous change in the amount of money held by the public (Chapra, 2000).

The existence of money in an economy gives the most important meaning, the injustice of measuring instruments caused by the instability of the exchange rate will result in the economy not running at the equilibrium point. This will make it even more difficult to realize justice in socio-economic and social welfare. Ibn 
Khaldun said that a country would not be able to carry out sustainable development without justice in its system. Price stability means guaranteed fairness of money in its function so that the economy will be relatively in a condition that allows the allocation of resources evenly, distribution of income, optimum growth, full employment and economic stability (Karim, 2007a). Thus, it is obligatory to maintain the value of money by adjusting the money supply according to need.

\section{B. METHOD}

This study uses a qualitative approach and descriptive methods, and was developed using literature studies in the form of books, literature or library materials to find expert opinions about a particular theme, then quote the opinions of these experts to strengthen the theoretical basis of research. The author analyzes and synthesizes various views and opinions of experts or the results of previous research, then the author describes and analyzes the research results and draws conclusions..

\section{RESULT AND DISCUSSION}

a. Islamic Money Concept

Etymologically, money comes from the word (nuqud). Nuqud is not found in the Koran or the Hadith of the Nabis. because the Arabs generally do not use this word to denote a price. They used the word "dinar" to denote currency made of gold, and the word "dirham" to denote a currency made of silver. They also used the word "wariq" to denote silver dirhams, and the word "'ain" to denote gold dinar. Meanwhile, "fulus" (copper money) is an additional medium of exchange for buying household goods (Hasan, 2005). In general, money is something that can be generally accepted as a means of payment in a certain area or as a means of paying debt, or a means of buying goods or services (Kasmir, 2018).

Money is used to facilitate human social economic activities which serve as a medium of exchange. Islamic Sharia teaches the use of money (in any form) to avoid exploitation between one human and another. In several Hadith, the Prophet Muhammad PBUH. advises not to exchange low quality commodities with good quality commodities (unless the quantity is the same) what should be done is to sell first the low quality commodities and then use the proceeds from the sale to buy good commodities (Ayub, 2009).

Development, money can be divided into four parts. Namely: 1). Commodity money, commodity money is money that has a commodity value. This means that commodities can be traded as goods when they are not used as money. 2) Metallic money, coins are money made of metal in the form of precious stones, iron, silver, etc. 3) Paper money, this type of money was first created in China in 910 AD as an attempt to make money lighter and easier to carry everywhere, and 4). Bank money, we now know bank money as a deposit or a banking account where the money we have is only nominal, but it can be physically owned at any time (Hasan, 2005).

Money is the most strategic factor in the functioning of any financial system. The status, value, role and function of money in Islamic finance is different from conventional finance. In the conventional system, money is considered a commodity that can be sold / bought and leased for a profit or rent that must be paid by one of the parties, regardless of usage or the role of money lent is in the hands of the borrower. The above case is very different from Islamic finance. Islamic economists recognize the benefits of money as a medium of exchange. This is done in order to avoid riba fadl as exemplified above (Ayub, 2009).

This money is born because there is a desire to require the same requirements and needs at the same time from the parties making the exchange. However, as needs become more complex, the main obstacle in making exchanges is the difficulty in obtaining the desired goods and services with the types of goods and services 
needed by other people or the difficulty of finding a common demand. In addition, the difficulty in determining the appropriate value for goods and suits being exchanged (Al-Arif, 2012).

\section{b. Islamic Monetary History}

Pada zaman Rasulullah saw. digunakan bimetallic standard yaitu emas dan perak (dirham dan dinar) because both are legal payment instruments circulating in the community. The exchange rate of gold and silver at the time of Rasulallah peace be upon him. This is relatively stable with a dinar-dirham exchange rate of 1:10, however, exchange rate stability has experienced disruption due to the disequilibrium between supply and demand. For example during the time of the Umayyads (41 / 662-132 / 750) the exchange rate ratio between dinars and dirhams was 1:12, while during the Abbasid period (132/750656/1258) it was in the range of 1:15.

At other times the dinar-dirham exchange rate fluctuated with a low exchange rate at the level of 1: 35-1: 50 . This instability in the exchange rate will result in bad coins out of circulations or bad quality will replace good quality money, in conventional literature this event is called Gresham's law. Like what happened during the reign of the Bani Mamluk (1263-1328), where the currency in circulation of fulus (copper) urged the existence of gold and silver coins by Ibn Taymiyyah. The monetary system throughout the ages has undergone many developments. It is this financial system that has the most empirical and historical studies conducted when compared to other economic disciplines. the financial system says that low quality money will kick out good quality money.

The development of gold as the standard of money in circulation has evolved three times, namely (Karim, 2007a): 1). The gold cins standard: where the precious gold metal is money which is active in circulation 2). The gold bullion standard: where the gold metal as the meter determines the exchange rate of money in circulation. 3). The gold exchange standard (Bretton woods system): in which the monetary authority determines the exchange rate of the domestic currency with foreign currencies that can be fully backed up by the gold reserves it owns. The rapid development of the financial system has given rise to fiduciary money (credit money), namely money that is not backed up by gold and silver.

Money as everything that is generally accepted as a means of payment (Mishkin, 2004). Historically, there have been at least three money systems: the commodity money system, the replacement money system, and the fiat money system. The commodity money system is a system in which money chosen by the public as a medium of exchange is in the form of a physical commodity. Historically, commodity money used was very diverse, ranging from stone, salt, rice, livestock, to gold. However, there is a tendency for one type of commodity to become dominant as currency, and this is gold (Newlyn \& Bootle, 1978). In this system, the money supply depends on the number of commodities available. So here, the monetary authority is only a place for printing money, where people can convert their goods into money coins (Cribb, 1986).

The second money system is a substitute currency system, in this system currency can be in the form of paper or coins or other materials which usually have no significant intrinsic value. This money can be exchanged for real value, in this case commodity currencies such as gold (Miller \& Van Hosse, 1993). Or to put it simply, its currency is simply a substitute for a commodity money. In terms of when this system started, there was no simultaneous use in the world. The Greek cities of Sicily and Southern Italy in 425 BC used bronze coins in daily trading transactions, while gold and silver were stored in the state treasury and only used for international trade (Cribb, 1986). However, the main period of the replacement money system was the Bretton Woods system which was based on a particular perception of how the international economy was run in the 1930s (Bordo \& Capie, 1993). This system ended later in 1973. From this it can be said that the replacement money system ended at the end of the Bretton Woods system in 1973 (Schwartz, 1987). In this system, there is a monetary 
authority that will issue currency and control it. In addition, private institutions can also issue notes representing the real money deposited.

The final monetary system is what is currently in operation. This money system is usually in the form of paper and coins which are completely unrelated to any commodity. With the development of technology, fiat money can be in the form of transaction accounts issued by financial institutions. With this, depositors can write checks for the purchase of goods and services. More than that, technological developments can make people transact just by clicking wherever they are. Of the three systems, Muslim economists have different opinions. There are groups who see that it is the commodity money system, in this case gold, which is compatible with Islam, and should be a monetary system.

\section{Basic Principles of Islamic Monetary}

Monetary policy in Islam is based on the following basic principles of Islamic economics (Karim, 2001):

1. The highest power belongs to Allah and Allah is the absolute owner

2. Humans are leaders (kholifah) on earth, but not the true owners

3. Everything that is owned and obtained by humans is because of the permission of Allah, and therefore the less fortunate brothers have the right to part of the wealth owned by their more fortunate brothers

4. Wealth must not be accumulated or hoarded

5. Wealth must be rotated

6. Eliminating the gap between individuals in the economy, can erase conflicts between groups

7. Establish obligations which are mandatory and voluntary for all individuals, including for members of the community who are poor.

In the technical aspect, Islamic monetary policy must be free from the elements of usury and interest. In Islam usury, which includes bank interest, is strictly forbidden.

\section{d. Islamic Monetary Objectives}

Monetary policy in Islam aims (Manan, 1997):

\section{Economic Prosperity with Full Employment Opportunities}

This goal is closely related to the maqosid of sharia. Economic welfare takes the form of the fulfillment of all basic human needs, the elimination of all major sources of difficulty and an increase in the quality of life morally and materially. Also the creation of an economic environment in which the caliph of Allah is able to use his time, physical and mental abilities for the enrichment of himself, his family and society. Welfare is not maximizing wealth and consumption for oneself regardless of others, or for certain groups and neglecting other groups.

Humans living in the world are the khalifah of Allah along with other humans who are also the khalifah of Allah as well. The resources available are for all human beings. Therefore the use of resources by individuals is legal, but limited in such a way that it does not endanger social happiness and goodness (Rahman, 1997). Even good for the social environment.

The use of resources must take into account Islamic values, which include (a) Material prosperity should not be achieved through the production of goods and services that are not essential and morally questionable. (b) It is not allowed to widen the social gap between the rich and the poor. (c) must not cause harm to current or future generations by destroying the physical and moral environment (Chapra, 2000).

\section{Socio-Economic Justice and Distribution of Income and Wealth}

Keadilan adalah meletakkan sesuatu pada tempat yang sebenarnya. Konsep ini mengandung dua unsur definition. (a) a form of balance and proportion between people who have rights. (b) A person's rights should 
be given and submitted carefully (Sidiqi, 1996). The values of justice are based on the principles of equality and brotherhood. Every individual has the same right to obtain wealth in improving the welfare of his life without distinguishing race and class and other differences.

Brotherhood means that every individual is a brother. They are Allah's creatures and must love each other (Tara, 2000). However, justice is not an equalization in the distribution of wealth. This is because each individual has differences that allow the acquisition of wealth. Nor is it the maximum control of wealth and maintaining wealth for oneself as a reflection of the right to work hard. This justice reflects that material rewards must be given fairly for the hard work of creativity and its contribution to the output. Wealth is indeed the result of individual efforts, but within that wealth there are other people's rights. Wealth must thus be distributed to those who have rights. In relation to this objective, central bank regulation must be realistic and reduce the concentration of wealth and power in the hands of a few people (Chapra, 2000).

\section{Money Value Stability}

The stability of the value of money has a major influence on economic life, both edologically and practically, because money determines the value and price of goods and services. The uncertainty of money causes economic damage, because the economic order is based on the principle of supply before demand, so predicting a price can be difficult to do (Saud, 1996).

The uncertainty of the value of money, which takes the form of inflation rather than deflation, shows that money cannot function as a fair and correct unit of account, and causes economic actors to behave unfairly to other actors without realizing it, by degrading monetary assets without their knowledge. . Inflation exacerbates the climate of uncertainty in which economic decisions are made, raises concerns about capital formation and leads to misallocation of resources.

And it even tends to destroy moral values because it provides rewards for speculative efforts which in the end impose losses on productive activities and exacerbate income inequality (Chapra, 2000). Stability of value for money is a top priority in Islamic monetary management activities. The stability of the value of money, which is reflected in the stability of the price level, greatly influences the realization of the achievement of a country's economic development goals, such as; fulfillment of basic needs, equitable distribution of income and wealth, optimum real economic growth rate, expansion of employment opportunities and overall economic stability (Siregar, 2001).

\section{e. Islamic Monetary Policy}

Monetary policy is an effort to control or direct the macro economy to the desired condition (which is better) by regulating the money supply. What is meant by better conditions is an increase in equilibrium output and / or maintenance of price stability (controlled inflation) (Rahardja \& Manurung, 2004).

Monetary policy is the rules and regulations issued by the monetary authority to control money supply, inflation, and to maintain the economic stability of a country. This can be achieved in several ways, such as changes in interest rates, open market operations, and amendments to certain asset reserves and deposits (Rivai, 2007).

In its implementation, the monetary policy strategy is carried out differently in each country, according to the objectives to be achieved and the transaction mechanisms that apply to the country's economy (Isra, 2015).

\section{f. Islamic Monetary Policy Instruments}

In the context of the Islamic monetary system, the issue that might be raised at this point in time is whether the conventional instruments meet the sharia standards? By looking at the monetary policy instruments above, 
what may be certain to be rejected is the discount rate because it involves the imposition of interest rates on loans provided by the central bank. Open market operations may also be an issue, if the securities being traded have an interest rate element. The statutory reserve requirement ratio is probably the least likely to be rejected, because its use may reflect monetary control as well as prudence in protecting depositors' funds.

Fundamentally, in carrying out its monetary policy, the central bank should not rely on the GWM ratio, because the GWM ratio is uncompromising and lacks flexibility, that is, the GWM ratio often results in wide swings in the money supply stock, which may affect prices and financial stability. adversely. In addition, the adoption of the GWM ratio cannot be reversed, should it be too contracted or too expanded.

Based on the losses held by the GWM ratio as a monetary policy instrument, the adoption of other policy tools is deemed essential. The main question is in the Islamic banking system, how should the central bank inject liquidity or reserves? The point is that open market operations may still be used as long as the government securities traded in the transaction are Islamic securities.

This clearly highlights the need for the development of Islamic capital markets (Soemitra, 2014), so that this instrument can be used effectively. The use of discount windows can still be used to increase the availability of credit in the banking system. However, the discount rate needs to be eliminated, so that lending activities comply with sharia principles. Adiwarman Karim divides Islamic monetary policy instruments into three schools, namely (Karim, 2007b):

1. The lqtishaduna School (Baqir Ash Shadr)

a) In the early days of Islam, there was no need for monetary policy due to the almost absence of a banking system and the minimal use of money

b) Money is exchanged for something that actually adds value to the economy

c) The velocity of money in a certain period is the same as the value of goods and services produced during the same period.

2. The second school aims to maximize existing resources so that they can be allocated to productive economic activities. Through the instrument "dues of idle fund" which can affect the size of the demand for money so that it can be allocated to increasing the productivity of the economy as a whole.

3. Alternative Schools of monetary policy through the "syuratiq process", where a policy taken by the monetary authority is based on prior deliberations with the real sector authority. So that there is a harmonization between monetary policy and the real sector.

g. Monetary Policy Implementation in Several Countries

application of Islamic monetary policy instruments in several countries including Indonesia (Karim, 2007b):

1. Sudan

The following are the monetary instruments used by the Central Bank of Sudan (BOS) in its operations: a) Reserve Requirement, each bank must reserve at least $20 \%$ of BOS deposits (100\% for foreign currency deposits) of total public savings funds (with excluding investment deposits) which are reflected in the bank's month-end balance sheet. b) Conventional banks must achieve and maintain a liquidity ratio of $10 \%$ of their savings funds in local currency. c) Credit limits for certain priority sectors such as: 1) Agriculture 2) Export 3) Industry 4) Mining and energy 5) Transportation and warehousing 6) Professionals, craftsmen, and small size 
family businesses 7) Public housing 8) Investment in the official khartoun stock market. Where a minimum of $90 \%$ of bank credit funds must be allocated to non-priority sectors, including demostic trade and services that are not related to the priority sector.

2. Iran

a) Reserve requirement ratio between $10 \%-30 \%$ b) Adjusted open market operation basically omo cannot be effectively used in countries whose financial markets are not yet developed c) Discount rates are due to prohibition against usury, this type of instrument is not used broad as in the conventional banking system. d) Credit ceiling to control money creation and liquidity growth by the monetary authority.

3. Indonesia

A bank based on Islamic sharia, BI carries out its functions as a central bank with the following instruments. a) Minimum Statutory Reserves (GWM): also known as statutory reserve requirement, is the minimum deposit of commercial banks in the form of demand deposits at $\mathrm{BI}$, the amount of which is determined by $\mathrm{BI}$ based on a certain percentage of thirdy party funds. Statutory Reserves are the bank's obligation to support the implementation of prudential banking principles and act as a monetary instrument that controls the amount of money circulation. b) Sharia Interbank Mudharabah Investment Certificate (IMA Certificate): an instrument used by Islamic banks that experience excess funds for profit. On the other hand, it is used as a means of providing short-term funds for Islamic banks that experience a lack of funds. c) Bank Indonesia Wadiah Certificate (SWBI): namely a Bank Indonesia instrument in accordance with Islamic sharia. SWBIs can also be used by sharia banks with excess liquidity as a means of short-term deposits of funds.

\section{CONCLUSION}

Islam has its own monetary policy that is different from other economic systems. In the aspect of the goal of Islam, it does not only emphasize equilibrium between the demand and supply of money but also strives for equality with the principles of justice and brotherhood, so as to create a fair distribution of wealth and income as well. In the management aspect, by not applying interest, Islam indirectly avoids the adverse effects of the interest system. The monetary crisis so far can be minimized by implementing profiles and los Sharing on financial intermediation which creates a more stable economy, because it can minimize the use of aggregate money demand for non-essential and non-productive activities, so that efficiency and equitable utilization of resources can be increased and macro imbalance. economy that causes inflation to be reduced.

Furthermore, because the main source of highpowered money generally comes from government loans to the central bank, in this case Islam demands the independence of the central bank and its consistency in achieving monetary targets. Without this, monetary policy will be difficult to implement. The central bank certainly has difficulty refusing government loans as long as it is under government interference. One thing needs to be paid attention to, that Islamic monetary management, which has been practiced in various countries, has a positive effect on a long-term period. To solve short-term problems, the most feasible instruments are the moral suasion and statutory resever requirement, in the form of an increase in mandatory reserves.

\section{REFERENCES}

Al-Arif, M. N. R. (2012). Lembaga Keuangan Syariah. CV Pustaka Setia.

Ayub, M. (2009). Understanding Islamic Finance, A-Z Keuangan Syariah (A. W. Pribadi, Trans.). PT Gramedia Pustaka Utama.

Bordo, M. D., \& Capie, F. (1993). Monetary Regimes in Transition. Cambridge University Press.

Chapra, M. U. (2000). Islam dan Pertumbuhan Ekonomi. Gema Insani Press. 
Cribb, J. (1986). Money: From Cowrie Shells to Credit Cards. British Museum Publication Ltd.

Hasan, A. (2005). Mata Uang Islami, Telaah Komprehensif Sistem Keuangan Islami. PT Raja Grafindo Persada.

Huda, N. (2009). Ekonomi Makro Islam: Pendekatan Teoritis. Kencana Prenada Media Group.

Isra. (2015). Sistem Keuangan Islam, Prinsip dan Operasi (T. Ellys, Trans.). Raja Grafindo Persada.

Karim, A. A. (2001). Ekonomi Islam Suatu Kajian Kontemporer. Gema Insani Press.

Karim, A. A. (2007a). Ekonomi Makro Islam. PT Raja Grafindo Persada.

Karim, A. A. (2007b). Ekonomi Makro Islami. PT Raja Grafindo Persada.

Kasmir. (2018). Manajemen Sumber Daya Manusia (Teori dan Praktik). PT Raja Grafindo Persada.

Manan, M. A. (1997). Teori dan Praktek Ekonomi Islam. Dana Bhakti Wakaf.

Miller, R. L., \& Van Hosse, D. D. (1993). Modern Money and Banking (3rd ed.). McGraw-Hill Book Co.

Mishkin, F. S. (2004). The Economics of Money, Banking, and Financial Markets (7th ed.). Pearson Addision Wesley.

Mujahidin, A. (2007). Ekonomi Islam. PT Raja Grafindo Persada.

Newlyn, W. T., \& Bootle, R. P. (1978). Theory of Money. Clarendon Press.

Pohan, A. (2008). Kerangka Kebijakan Moneter dan Implementasinya di Indonesia. PT Raja Grafindo Persada.

Rahardja, P., \& Manurung, M. (2004). Teori Ekonomi Makro Suatu Pengantar. Fakultas Ekonomi Universitas Indonesia.

Rahman, A. (1997). Doktrin Ekonomi Islam (Vol. 1). Dana Bhakti Primayasa.

Rivai, V. (2007). Bank and Financial Institution Management. Raja Grafindo Persada.

Sakti, A. (2007). Analisis Teoritis Ekonomi Islam Jawaban Atas Kekacauan Ekonomi Modern. PARADIGMA \& AQSA Publishing.

Saud, M. A. (1996). Garis-Garis Besar Ekonomi Islam. Gema Insani Press.

Schwartz, A. J. (1987). Money in Historical Perspective. The National Bureau of Economic Research.

Sidiqi, M. N. (1996). Kegiatan Ekonomi Islam. Bumi Aksara.

Siregar, M. (2001). Menejemen Moneter Alternatif, dalam Dinar Emas Solusi krisis Moneter. Sirac. SEM Institud. Infid.

Soemitra, A. (2014). Bank dan Lembaga Keuangan Syariah. Kencana.

Suprayitno, E. (2005). Ekonomi Islam: Pendekatan Ekonomi Makro Islam dan Konvensional. Graha IImu.

Tara, M. A. D. (2000). Strategi Pembangunan Ekonomi Kerakyatan. Nuansa Madani. 